\title{
Lean Startup: A comprehensive historical review
}

\begin{tabular}{|r|l|}
\hline Journal: & Management Decision \\
\hline Manuscript ID & MD-07-2017-0663.R1 \\
\hline Manuscript Type: & Original Article \\
\hline Keywords: & $\begin{array}{l}\text { historical review, business model validation, Lean Startup, startups, } \\
\text { Learning School }\end{array}$ \\
\hline \multicolumn{2}{|l}{} \\
\hline
\end{tabular}

\section{SCHOLARONE \\ Manuscripts}


Article classification

Abstract

Keywords

\section{LEAN STARTUP: A COMPREHENSIVE}

\section{HISTORICAL REVIEW}

\section{Literature Review}

Purpose: The primary goal of a startup is to find a viable business model that can generate value for its customers while being effectively captured by the startup itself. This business model, however, is not easily defined, being a consequence of the application of tools involving trials, data analyses and testing. The Lean Startup methodology proposes a process for agile and iterative validation of business models. Given the popularity and importance of such methodology in professional circles, this paper aims to conduct a historical literature review of existing academic and professional literature, correlating Lean Startup concepts and activities to previous theory and alternative business model validation methods.

Methodology: A historically-oriented systematic literature review employing snowball sampling was conducted in order to identify academic and professional literature and references for iterative validation of business models. A total of 12 scholarly journals and professional magazines dealing with strategy, innovation, entrepreneurship, startups and management were used as data sources. Our extensive literature review resulted in 963 exploratory readings and 118 papers fully analyzed.

Findings: Our results position the Lean Startup as a practical-oriented and up-to-date implementation of strategies based on the Learning School of strategy-making and the Effectuation approach to Entrepreneurship; we also identify a number of methods and tools that can complement the Lean Startup principles.

Originality/value: This paper identified and synthesized the scientific, academic and professional foundations that precede, support and complement the main concepts, processes and methods advocated by the Lean Startup methodology.

Startups, historical review, business model validation, Lean Startup, Learning School, Strategy, Effectuation 


\section{Introduction}

There is no single, universally accepted definition of 'startup' (Eisenmann et al., 2011; Paternoster et al., 2014). For Eisenmann et al. (2011), startups are ventures created to launch new products in the market. Ries (2011) describes startups as ventures designed to create a new product or service under market conditions of great uncertainty. Similarly, Blank (2007) understands that the main objective of a startup should be to find a repeatable and scalable business model.

A business model defines how a firm creates and delivers value to its customers, while capturing a share of it so as to be economically and financially sustainable (Teece, 2010). Unlike large firms, startups find it difficult to use traditional business planning (Blank, 2013), whose premise is that future results can be extrapolated based on the analysis of past experiences (McGrath 2010), because there is no past experience in a startup besides the uncertainty of its essentially innovative nature. As Picken (2017) argues, startups must overcome numerous transition hurdles during their growth and maturation, and fixed plans rarely survive these transitions. A business model is rarely fixed and is usually built upon trial and experimentation, especially in new ventures (Cortimiglia et al., 2016; Cosenz \& Noto, 2018; Yang et al., 2018). According to Magretta (2002), when a firm starts to operate, the hypotheses that form its initial business model, including motivational and economic issues, are subject to constant market test and validation. The success of an organization comes from the ability to adapt its business model dynamically and effectively. Maintaining a viable long-term business model, thus, must be an entrepreneur's constant task (Teece, 2010).

Based on the abovementioned premises, a growing stream in Entrepreneurship theory argues that startups typically evolve their business model through constant experimentation and learning (Sarasvathy, 2001; Baker \& Nelson, 2005; Fisher, 2012; Kerr et al., 2014; Picken, 2017). Recently, Ries (2011) created the movement known as Lean Startup (LS), from the eponymous work, by proposing a Business Model Validation (BMV) methodology based on rapid iterations. It was not the first time such an approach has been proposed to the general public. Before Ries, authors such as McGrath and MacMillan (2000), Sarasvathy (2001), Baker and Nelson (2005) and Blank (2007) had already challenged the business plan framework as the foundation of new ventures. However, the success of Ries' book was unprecedented: hundreds of thousands of copies were sold in short time, and his theories became known and used worldwide, becoming a reference among entrepreneurs (Blank 2013; Greenwald 2012; 2018: Yang et al., 2018) and almost standard practice when launching new startups. Even among the rapidly expanding popular business literature on how to successfully create new ventures (see Anthony, 2014; Arteaga \& Hyland, 2014; Furr \& 
Ahlstrom, 2011; Maurya, 2012; Furr \& Dyer, 2014), Ries' LS surely stands out in terms of popularity with and impact on practitioners.

However, the work by Ries (2011), possibly due to its eminently practical approach and its focus on hands-on prescriptive advice, lacks a strong theoretical background (Frederiksen \& Brem, 2017; Berglund et al., 2018; Contigiani and Levinthal, 2018; Ghezzi and Cavallo, 2018: Yang et al., 2018). Occasionally, the author cites sources of inspiration throughout the text or in notes, or makes suggestions for complementary reading, but avoids further analysis of the LS background although Frederiksen and Brem (2017) conjectured that this background would probably not be unknown to Ries. In any case, such apparent lack of explicit grounding in previous scholarly tradition can be argued to be a reason for a somewhat lackluster reception of LS as a research theme among entrepreneurship academics. In fact, a recent study mapping the scientific field of entrepreneurship has failed to identify LS as a cohesive research topic (Landström \& Harirchi, 2018). Additionally, although the LS movement originated in the software industry, there is very little systematic empirical investigation on LS applicability and effectiveness in the real world, as most research tend to focus on instances of use in isolated settings (e.g., single companies or sectors) (Power, 2014; Edison et al., 2018) or entrepreneurship education (Harms, 2015; Mansoori, 2017). We posit that a more rigorous analysis of the academic antecedents of LS may provide important insights about its implementation challenges as well as its merits and shortcomings.

Given the importance and popularity of the LS with entrepreneurs from around the world, this article presents a historical review of academic and professional works about BMV methods and related concepts that were published previously or subsequently to emergence of the LS phenomenon. This review aims to clarify two questions: (Q1) which are the key scientific, academic and professional concepts and theories that may have inspired the LS?, and (Q2) how does academic and professional knowledge prior to the LS can help complement the study and understanding about this methodology? Answering these questions will enable authors' to addressed the research gaps identified.

The paper is structured in five sections. Following this Introduction, in Section 2 we present a brief review on startups, business models and the LS methodology. Next, the methodological procedures are outlined in Section 3, while the main results are presented and discussed in Section 4. Finally, in Section 5 we draw conclusions and discuss the main implications of our findings for future development of theory and practice of entrepreneurship.

\section{Startups, Business Models and Lean Startup}


This section offers an overview of startups, business models, and a brief description of the LS methodology.

\subsection{Startups}

The creation of a new business venture is recognized as a difficult, complex and risky process (Chrisman et al. 2005; Trimi \& Berbegal-Mirabent 2012). A factor related to the risk associated with startups addresses the need to deal with uncertainty in different perspectives: market, product, competitiveness, people and finances (Paternoster et al. 2014; Sull 2004; Chang 2004). In this sense, for Eisenmann et al. (2011) the greatest risk that an entrepreneur may come across is to offer the market a product that no one wants or needs. All this uncertainty makes investors, potential employees, suppliers and buyers hesitate when it comes to providing resources for the startup (Chang 2004). Such question leads to another feature associated with this type of organization, the one of naturally having limited economic, human and physical resources. Therefore such resources should be effectively implemented and managed (Mcgrath \& Macmillan 1995; Drori et al. 2009; Paternoster et al. 2014).

These conditions contribute to the high failure rates of startups (Stinchcombe 1965; Chang 2004). Besides the factors mentioned, Trimi and Berbegal-Mirabent (2012) argue that a major cause of failure in startups is the lack of a structured process to discover and understand their markets, identify their customers and validate their hypotheses in the early stages of design. On the other hand, startup failures could be avoided or at least their related costs could be reduced if managers of new ventures based on innovation would use the appropriate tools for control and planning (McGrath \& MacMillan 1995). 


\subsection{Business Models}

Although the term 'business model' has been part of the business world's jargon for a considerable amount of time (Casadesus-Masanell \& Ricart 2010), the concept began to be studied more carefully after the second half of the 1990s. Since then, it has been a recurring topic in academic studies and papers (e.g, see Osterwalder et al. 2005; Zott et al. 2011; Martikainen et al. 2014). One of the factors contributing to the increase in interest for the expression was the growth of the Internet itself and its impact on traditional business strategies (Zott et al. 2011; Osterwalder et al. 2005).

Despite numerous studies, there is no agreed definition for the concept of business model (Casadesus-Masanell \& Ricart 2010; Zott et al. 2011; Massa et al., 2017). For Magretta (2002), a business model should be a representation of how the company operates, told through a story. For Chesbrough and Rosenbloom (2002), the business model is a device that demonstrates the connection between technological development and the creation of economic value. CasadesusMasanell and Ricart (2010) seek to separate and at the same time relate the business model concepts and strategy, and define the business model as a reflection of the company strategy. More objectively, Teece (2010) describes business model as defining the way the company creates and delivers value to customers and how to convert the payments received in profit. Zott and Amit (2013, p.404), in a similar way, believe that the business model "describes how the company conducts its business."

Different authors analyzed or proposed analytical dimensions of a business model (Chesbrough \& Rosenbloom 2002; Osterwalder et al. 2005), which could be summarized as: (i) value proposition; (ii) value creation; (iii) value delivery; (iv) value appropriation; and (v) value networking (Cortimiglia et al. 2016). Value proposition refers to an overview of the several products and services offered to the customer by the company (Osterwalder et al. 2005). Creating value refers to the company's unique internal characteristics to determine its market approach, including resources, processes and skills needed to create value. Delivering value, in turn, refers to how the company is organized to deliver value to customers and partners, including the distribution chains. Value appropriation defines how the company captures value and generates profit. Finally, value networking demonstrates how the firm cooperates with other organizations to create value for customers (Cortimiglia et al. 2016). 


\subsection{Lean Startup}

One of the common definitions of a startup is of a temporary organization designed to search for a repeatable and scalable business model (Blank 2007). In this sense, the consensus among scholars is that a nascent company, in early stages of operation, most of the time does not have a consolidated and viable business model that is able to sustain the organization's long-term goals (Chesbrough \& Rosenbloom 2002; Chrisman et al. 2005; Teece 2010). It is common, for example, for entrepreneurs to start new businesses with only some rudimentary concepts in mind (Gruber 2007) as well as severely limited resources to make do with (Baker and Nelson, 2005). As argued by Chesbrough and Rosenbloom (2002), the initial business model of a company is a hypothesis or vague idea of how to deliver value to the customer. Teece (2010) complements, stating that the ideal business model rarely appears in the early stages of a new business.

In environments and situations of great uncertainty, complexity and speed of change, especially for new business ventures or startups, many scholars believe that success comes from the speed at which the organization can conduct tests and experiments, learn and evolve from its business model (Mcgrath \& Macmillan 1995; Lynn et al. 1996; Osterwalder \& Pigneur 2010). More specifically, it is considered that Internet-based enterprises are the perfect example of an environment in which the speed of business creates the need for business models to be constantly tested and adjusted (Wirtz et al. 2010).

To achieve this cycle of evolution from their business model, startups must implement light and simple methods and processes that allow to iterate and evolve from basic prototypes of products through the constant customer feedback opinion (Paternoster et al. 2014). In this sense, Ries (2011) has coined the term Lean Startup to describe a methodology oriented to help organizations to carry out experiments and iterate when looking for a sustainable business model. His work has gotten wide repercussions in the market and attention from new entrepreneurs (Eisenmann et al. 2011; Blank \& Dorf 2012).

The methodology presented by Ries (2011) centers on a Build-Measure-Learn (BML) process called, similar to the cycles PDCA (Plan-Do-Check-Act) by Deming (1986) and OODA (Observe-Orient-Decide-Act) by Boyd (1986). The synthetic process is shown in Figure 1, adapted from Ries (2011). 


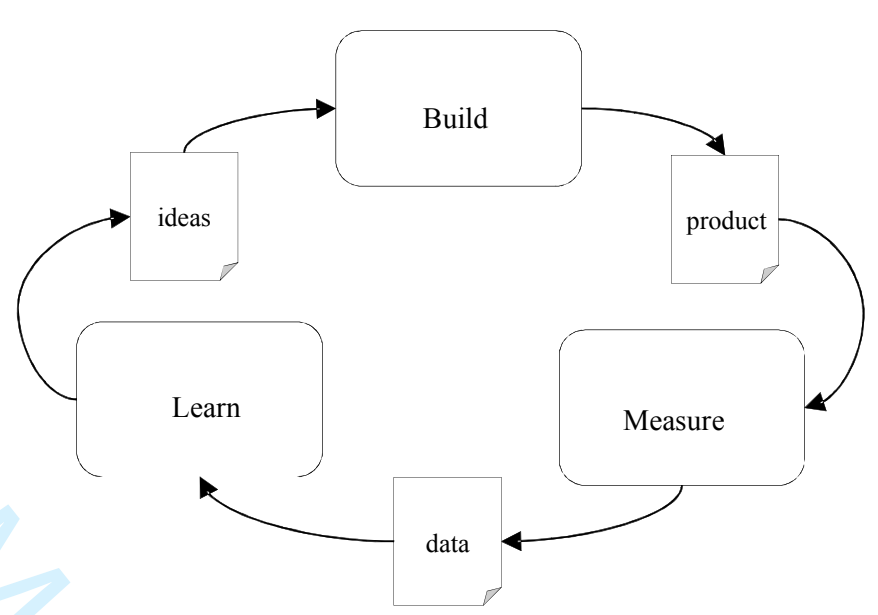

Figure 1 - BML process

For a better analysis, this process was divided into its constituting activities, which are reported in Figure 2, adapted from Ries (2011), Eisenmann et al. (2011) and Blank and Dorf (2012).

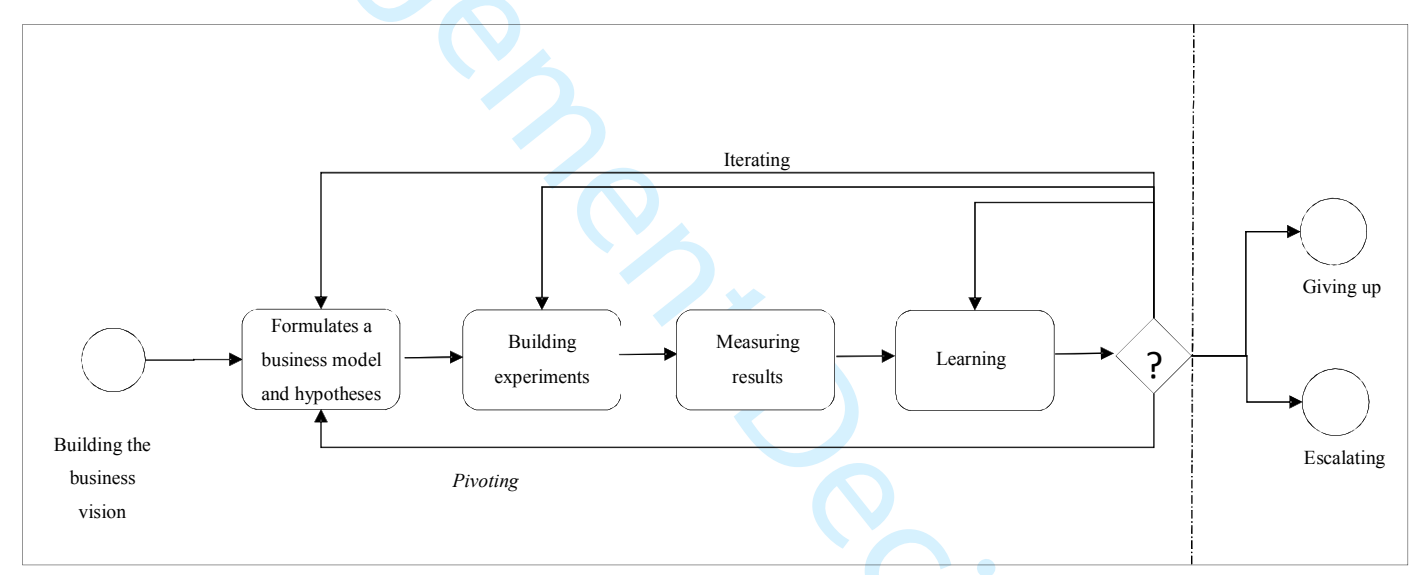

Figure 2 - The $L S$ process

In relation to Figure 2, the following steps are described:

i. Building the business vision: Also known as ideation, it is the stage where there is the creative process of generating ideas and designing the business that the entrepreneur wants to develop (Mueller \& Thoring 2012). The business vision should stay the same while the BML cycle is run, being discarded only if the experiments result in enough negative perceptions. The ideation phase is not explicitly part of the LS methodology;

ii. Formulating the business model and hypotheses: In this step, the delivery model of value to customers is designed. A hypothesis is a formalization of explicit or implicit 
assumptions about one or more dimensions of the business model, initially considered uncertain or doubtful (Blank \& Dorf 2012). The results of this step are always ideas;

iii. Building experiments: An activity of scientific nature in which the researcher or entrepreneur, through the manipulation of controlled variables, notes the variation of independent variables. They are used to test the business model hypotheses. There are several types of experiments, such as qualitative interviews, a/b tests, prototypes, launch pages, MVPs (Minimum Viable Product), smoke tests and concierge (Blank \& Dorf 2012);

iv. Measuring results: Through data analysis and using statistical tools, the entrepreneur must measure and monitor the results of their experiments and confront them with previously defined hypotheses;

v. Learning: a key concept and goal in the early stages of a startup. It consists of confirming or ruling out hypotheses through experiments. Ries (2011) calls this validated learning, whose outcomes fall into four categories: pivoting, iterating, escalating, and giving up. After conducting an experiment and discarding a hypothesis, pivoting it is the action of radically changing one or more dimensions of the business model in order to formulate a new hypothesis and test it through new experiments (Blank \& Dorf 2012). Iterating is a less radical change than pivoting. Thanks to the learning acquired, it consists of promoting one or more changes in the business model or product to test the new hypotheses. Generally, iterations have a positive value, as they mean the startup is approaching a viable business model (Blank \& Dorf 2012). Escalating it is the situation in which entrepreneurs believe that they have found a sustainable business model and are willing to invest more in the business in order to create an functioning organization around it and obtain economies of scale (Blank \& Dorf 2012). Giving up occurs when tests and experiments show that the business vision set is not able to generate a sustainable business model.

\section{Methodological Procedures}

As Webster and Watson (2002) argue, emerging topics benefit from literature reviews aimed at identifying and exposing theoretical foundations. In order to locate contributions in academic and practitioner-oriented literature that can be thought of antecedents to the LS methodology, we conducted a systematic literature review using three types of sources: (i) articles in scientific and 
professional journals; (ii) entrepreneurship, business and management books published prior or after Ries (2011); and (iii) additional relevant references found in the bibliographies of the works surveyed in (i) and (ii), obtained by snowball sampling (Biernack et al., 1981; Wohlin, 2014). All analyses were carried out during the first half of 2016 and updated in early 2018. Instead of literature reviews' usual focus on recent or current literature, we opted for a historically-oriented analysis of the source items, aiming at producing an overview in the form of a narrative perspective of the antecedents of the Lean Startup methodology (Grant \& Booth, 2009). However, differently from typical narrative reviews, we adopted quality assessment criteria for searching and appraising the literature, as suggested by Tranfield et al. (2003) in their guidelines to systematic literature reviews.

The methodological procedures were inspired by the structured approach to determine the source material for a literature review proposed by Webster and Watson (2002). First, a search in top scholarly journals and professional magazines dealing with strategy, innovation, entrepreneurship, startups, and management was conducted. The initial list of sources was a ranking of the 20 most relevant publications in the category 'Entrepreneurship and Innovation' according to Google Scholar (2018), ordered by their five-year h-index. This list was compared to and supplemented by high ranking entrepreneurship and innovation sources identified by Thongpapanl (2012), Ratinho et al. (2015) and Landström and Harirchi (2018). The resulting 72 publications were ordered by Journal Impact Factor (JIF). Although JIF is often used as a proxy for journal propensity to publish high impact research (Thelwall, 2008; Zhang et al., 2017), quality assessment can be improved by combining it with other indexes (e.g., Zupic and Cater, 2015; Vogel et al., 2017). Thus, for each of the 72 publications, five-year h-index (obtained from Scopus) and JIF (obtained from the Thomson Reuters' Journal of Citation Reports) were calculated in proportion to the highest value of the index in the sample and the average of the indices for each publication was calculated. Finally, the 12 publications with the highest overall average were selected (Table 1).

\begin{tabular}{cccc}
\hline Journal & h5-index & JIF & Average \\
\hline Research Policy & 77 & 3.117 & 0.923736 \\
Journal of Business Venturing & 63 & 3.678 & 0.909091 \\
Entrepreneurship Theory and Practice & 58 & 3.144 & 0.80403 \\
Technovation & 48 & 2.526 & 0.655081 \\
Technological Forecasting and Social Change & 50 & 2.058 & 0.604447 \\
Harvard Business Review & 58 & 1.574 & 0.590598 \\
Small Business Economics & 48 & 1.795 & 0.555707 \\
Journal of Product Innovation Management & 47 & 1.696 & 0.535755 \\
International Small Business Journal & 34 & 1.8 & 0.465477 \\
MIT Sloan Management Review & 33 & 1.529 & 0.422143
\end{tabular}


Table 1 - Selected publications

The following search string was used to search in the 12 selected publications: (startup OR "new venture" OR "new business") AND "business model" AND (lean OR hypothesis OR experiment* OR test OR learn*). As we were conducting a historical review, we did not limit our search to specific time periods.

For the second group of references, we used direct and indirect works cited by Ries (2011), Internet pages by Blank (n.d.) and Ries (n.d.), and participant observation within mailing lists and virtual communities focused on entrepreneurship. During this research, a large number of books based on or inspired by Ries (2011) were found. The third group of references was obtained by snowball sampling (Wohlin, 2014).

For each reference included in our review, a first exploratory reading was carried on the title and abstract, aiming to verify to what extent that specific work was relevant to the research. Next, we conducted an analytical reading of selected works to decide if the main topic explored, directly or indirectly, at least one of the activities of the LS process depicted in Figure 2. If the article or book referenced additional works that addressed the topic at hand, that bibliographic reference was included for further exploratory and analytical reading. Otherwise, the work was discarded. Our extensive literature review resulted in 963 exploratory readings and 118 analytical readings, as detailed in Table 2.

\begin{tabular}{ccc}
\hline Research & $\begin{array}{c}\text { Exploratory } \\
\text { reading }\end{array}$ & $\begin{array}{c}\text { Analytical } \\
\text { reading }\end{array}$ \\
\hline (i) Articles in scientific or professional journals & 890 & 70 \\
(ii) Current reading works related to Ries (2011) & 13 & 8 \\
(iii) References found in the first and second groups & 60 & 40 \\
Total & 963 & 118 \\
\hline
\end{tabular}

Table 2 - Summary of the works reviewed

\section{Results and Discussion}

These sources were analyzed according to the two questions that guided our research.

4.1 Which are the key previous scientific, academic and professional concepts and theories that may have inspired the LS methodology? 
To answer this question (Q1), we sought similarities between concepts of LS and concepts previously discussed by other authors found during the literature review. Objectively, we found that the main theoretical and conceptual bases that explain and academically justify the LS methodology are (i) explicit on the concepts that characterize the Lean philosophy of management (Deming, 1986; Ohno, 1988; Krafcik, 1988; Womack et al., 1990), (ii) implicit in the implementation of principles of the Learning School of strategy (Lindblom, 1959; Quinn, 1978; Mintzberg, 1978) and (iii) implicit on the emerging streams of Effectuation (Sarasvathy, 2001) and Bricolage (Baker and Nelson, 2005) concerning Entrepreneurship theory of new venture formation.

By including the word Lean in the name of his methodology, Ries (2011) seeks to bring it closer to the works by Deming (1986), Ohno (1988) and Womack, Jones and Roos (1990), specifically on the core principles and the methods and tools of the Lean approach. The word Lean was used for the first time by Krafcik (1988) as a generalization of the so-called Toyota Production System (TPS). Initially, the author intended to differentiate the production model of companies like Toyota Motor Corporation from the Western automotive industries, known by the mass production model (Holweg 2007). According to the Toyota Production Support Center (2015), TPS is based on four principles: (i) providing customers with what they want, when they want it, and in the amount they want it; (ii) people are the most important resource; (iii) continuous improvement, with the constant engagement of everyone; and (iv) an operational focus.

In this sense, the LS has its most explicit origins in the basics of Lean Manufacturing and TPS, notably by: (i) seeking to reduce waste by creating minimum prototypes of functionalities in products and seeking customer feedback to evolve (Moogk 2012); (ii) working with improvement cycles and continuous evolution, known as kaizen in TPS (Eisenmann et al. 2011; Haines 2014); and (iii) implementing an improvement process, BML, an adaptation of the process Plan-Do-CheckAct (PDCA), credited to Deming in the 1950s (Trimi \& Berbegal-Mirabent 2012). A recent study from Ghezzi and Cavallo (2018) explicitly compared the principles from Lean Manufacturing and Lean Startups (Table 3), thus identifying the key touchpoints in such inherent relationship.

\begin{tabular}{|c|c|}
\hline Lean Manufacturing & Lean Startup Approaches \\
\hline Create value for the customer & $\begin{array}{l}\text { Build a Minimum Viable Product (MVP) to understand what } \\
\text { customers want and validate your business model }\end{array}$ \\
\hline Identify the value stream & Design a Lean Canvas \\
\hline Create flow & Trigger a continuous Deployment Cycle \\
\hline Produce only what is pulled by the customer & $\begin{array}{l}\text { Get out of the building (GOOB) and learn what customers ask } \\
\text { for }\end{array}$ \\
\hline Pursue perfection & Follow a Build-Measure-Learn (BML) cycle \\
\hline
\end{tabular}


Table 3 - Lean Manufacturing principles in Lean Startup: touchpoints - adapted from Ghezzi and Cavallo (2018)

Moreover, and implicitly, we argue that the LS methodology and the BML method proposed an contemporary and specialized approach to implement the principles of the Learning School of strategy (Mintzberg et al. 1998) or Adaptive Approach (Miles et al., 1978). It is contemporary because it considers the speed of the changes resulting from the latest technological revolutions such as the Internet, which is a critical factor of change and learning. At the same time, it is specialized because its focus on helping organizations of a specific type, the startups.

We found that the dimensions of the Learning School and the principles, practices, techniques and methods of the LS highly overlap. Both are based on experimentation, learning and managing projects in complex situations and great unpredictability. Table 4, adapted from Mintzberg et al. (1998), shows the main aspects of this relationship.

\begin{tabular}{|c|c|c|}
\hline Analysis Dimension & Learning School & $\begin{array}{l}\text { Adherence of the Lean } \\
\text { Startup }\end{array}$ \\
\hline Target audience & $\begin{array}{l}\text { People inclined to experimentation and } \\
\text { adaptability }\end{array}$ & High \\
\hline Desired message & Learning & High \\
\hline Message provided & Playing (instead of chasing) & High \\
\hline Motto & $\begin{array}{c}\text { "If at first you do not succeed, try } \\
\text { again." }\end{array}$ & High \\
\hline Keywords & $\begin{array}{l}\text { Incrementalism, emerging strategy, } \\
\text { entrepreneurship, adventure, core } \\
\text { competencies }\end{array}$ & High \\
\hline Strategy & Standards, unique & High \\
\hline Central process & Emerging, informal, descriptive, messy & Moderate \\
\hline Change & $\begin{array}{l}\text { Continuous, incremental or fragmented, } \\
\text { with an occasional quantum view }\end{array}$ & High \\
\hline Central actor & Anyone who can learn & High \\
\hline Organization & Eclectic, flexible & High \\
\hline Leadership & $\begin{array}{l}\text { Sensitive to learning (from self and } \\
\text { others) }\end{array}$ & \\
\hline Environment & Elaborate, unpredictable & High \\
\hline Best suited to situations & Complex, dynamic and unpredictable & High \\
\hline Best suited to organizations & Adhocracies, decentralized & High \\
\hline
\end{tabular}

Table 4 - Dimensions of the Learning School of strategy and their relationship to the Lean Startup methodology

Lindblom (1959) was among the first authors to propose the development of a different kind of strategy than the formal, traditional strategic planning. By analyzing public policy-making methods, he noticed that the essential resource used by managers in strategy making is their own experience. The strategy therefore would be the result of a series of individual decisions over time that would connect to a larger outcome. Quinn (1978) developed this perspective concluding that in 
situations of unexpected external or internal events managers should use what he called 'logical incrementalism'. In these situations, managers would make urgent interim decisions that would change the strategic positioning of the company. Mintzberg (1978) observed the differences between what he called 'deliberate strategy' and 'emerging strategy' used by companies. The emerging strategy, as opposed to the deliberate strategy (also known as 'classical' or 'systematic'), differs by driving the company's strategic evolution through experimentation, learning and discovery, in contrast to the use of formal and analytical plans (Cortimiglia et al. 2016). These theories are commonly grouped under the Learning School umbrella (Mintzberg et al. 1998), highlighting their emphasis on lifelong learning as a driver, orientation and essential component of company strategy.

The single aspect of the LS that does not directly relate to principles of the Learning School regards its central process. While Mintzberg et al. (1998) understand that the strategy arising from the Learning School 'emerges' from a series of initially unconnected actions, the LS is precisely the attempt to propose a scientific, centralized and formal method for carrying out this process.

Our literature review also allowed us to find antecedents of the LS in the Entrepreneurship theories of Effectuation and, to a lesser extent, Bricolage. According to Sarasvathy (2001 - p 245), "Effectuation processes take a set of means as given and focus on selecting between possible effects that can be created with that set of means". As opposed to Causation, the entrepreneurial approach which advocates the use of goal setting and planning - the result of which are to be included in a well-structured business plan - to help new ventures facing a risky environment which is the result of past conditions, Effectuation posits that the the startup's environment is rather uncertain than risky - since events' probability of occurrence and related expected returns cannot be forecasted; therefore, startups should experiment rather than plan, doing their best with the limited or "bootstrapped" resources they have to leverage contingencies, their decisions being driven by the notion of affordable loss rather than expected return (Sarasvathy, 2001; Frederiksen and Brem, 2017; Yang et al., 2018).

A similar stance towards the activity of iterating and experimenting to validate a startup's feasibility is presented in the Entrepreneurial Bricolage view from Baker and Nelson (2005). These authors revisit the traditional though fuzzy notion of Bricolage from Levi-Strauss (1966) for the entrepreneurship domain: Bricolage hence is defined as "making do by applying combinations of the resources at hand to new problems and opportunities" (Baker and Nelson, $2005-\mathrm{p}$ 333). The LS then looks as an operational way to tackle resource scarcity and depleted and constrained 
environments, by offering entrepreneurs a process to make hypotheses that possibly challenge such environments; design and conduct experiments with limited efforts, through a viability testing which shall be minimum - as in the MVP; recombine their resources in different experiments according to new problems and opportunities emerging from the validated learning; and understand how to best "make do" notwithstanding their constraints.

\subsection{How can academic and professional knowledge prior to the LS help complement the study and understanding about this methodology?}

The historical literature review also allowed us to answer our second question (Q2). To do so, we found clear and solid references in the academic and professional circles that propose concepts closely related to the LS. These references can be divided into three groups: (i) similar or complementary methods for BMV, (ii) tools and techniques to support the implementation of BMV; and (iii) criticism, counterpoints or limitations to the learning-oriented strategy. The references that constitute the first group are summarized in Table 5.

\begin{tabular}{|c|c|c|}
\hline Reference & Method & $\begin{array}{l}\text { Main concept of the method and contribution } \\
\text { to the Lean Startup }\end{array}$ \\
\hline $\begin{array}{l}\text { Block and Macmillan } \\
\text { (1985) }\end{array}$ & Milestone Planning & Planning based on 'milestones' \\
\hline $\begin{array}{l}\text { Sykes and Dunham } \\
\text { (1995) }\end{array}$ & Critical Assumption Planning & $\begin{array}{l}\text { Business uncertainty reduction through experiments } \\
\text { prioritized by the associated cost }\end{array}$ \\
\hline $\begin{array}{l}\text { Mcgrath and MacMillan } \\
\text { (1995) }\end{array}$ & Discovery-Driven Planning & $\begin{array}{l}\text { Planning based on learning and release of resources based } \\
\text { on achieving checkpoints }\end{array}$ \\
\hline $\begin{array}{l}\text { Lynn, Morone and } \\
\text { Paulson (1996) }\end{array}$ & Probe and Learn & $\begin{array}{l}\text { Releasing 'immature products' in the market in order to get } \\
\text { feedback from customers and reduce risk }\end{array}$ \\
\hline Sarasvathy (2001) & Effectuation & $\begin{array}{l}\text { Experimenting with a set of means given, targeting } \\
\text { affordable loss rather than expected return and leveraging } \\
\text { contingencies and feedbacks from customers }\end{array}$ \\
\hline Sull (2004) & Disciplined Entrepreneurship & $\begin{array}{l}\text { Reducing risk by making assumptions about the business } \\
\text { and running experiments to test them }\end{array}$ \\
\hline Baker and Nelson (2005) & Entrepreneurial Bricolage & $\begin{array}{l}\text { Making do with the resources at hand when tackling new } \\
\text { problems and opportunities }\end{array}$ \\
\hline Blank (2007) & Customer Development & $\begin{array}{l}\text { Product development based on the evolution of knowledge } \\
\text { and understanding customer needs }\end{array}$ \\
\hline $\begin{array}{l}\text { Mullins and Komisar } \\
\text { (2010) }\end{array}$ & Journey to Plan B & $\begin{array}{l}\text { Framework and monitoring panel to validate assumptions } \\
\text { about the business }\end{array}$ \\
\hline
\end{tabular}

Table 5 - BMV similar or complementary methods

Block and Macmillan (1985) argue that organizational planning should be based on the achievement of significant events, not specific dates. Such events are called milestones, which give meaning to the name of the method: Milestone Planning. The achievement of a milestone comes with validating a hypothesis about the business, reviewing the plan and setting new milestones. The 
concept of milestone is not explicitly explored by Ries (2011), but it can clearly help reinforce the BML cycle.

Sykes and Dunham (1995) develop a practical and disciplined process for managing risks of business development that focuses on learning. Called Critical Assumption Planning (CAP), the process maximizes learning about new markets at the lowest cost possible. The main uncertainties in the business proposal are isolated as critical planning assumptions, which are then tested. The test sequence is determined by the uncertainty reduction potential per dollar of test cost. Overall, the method is similar to the LS but it includes new concepts related to financial measurement in each stage of the cycle, which are largely absent in the typical LS implementations.

The theory developed by Mcgrath and MacMillan (1995) also differs from traditional formal planning. Discovery-Driven Planning states that organizations operating in high-uncertainty environments must implement processes of evolution in which funds are released and invested in the company as it reaches certain goals or checkpoints. In this scenario, it is believed that the organization can learn and evolve between a checkpoint and another, possibly modifying its original plan in response to the continuous change that characterizes turbulent competitive environments. It is one of the best structured and known methods prior to the LS, and adds important concepts such as checkpoints and how to manage the use of financial resources, which are topics not explored by Ries (2011).

Lynn, Morone and Paulson (1996) coined the expression Probe and Learn to describe the iterative process in which, through the launch of a product considered immature within controlled parameters, the organization can study and learn more about the dynamics of the market and subsequently launch an improved product. The idea of an 'immature product' is similar to the MVP concept described by Ries (2011) and the Probe and Learn method contributes to LS product development cycle.

Concerning Effectuation (Sarasvathy, 2001) and Entrepreneurial Bricolage (Baker and Nelson, 2005), as discussed in Section 4.1, the emphasis placed on experimenting with limited resources and interacting early and often with customers to quickly understand whether the startup's business model is feasible and sustainable or not (Fisher, 2012), is consistent with several claims Ries (2011) made, including: the need to experiment and test to perform BMV, so as to disclose contingencies coming from customer feedbacks; the importance of limiting the resources committed to such testing through the building of MVPs; and the notorious "fail fast" statement about the 
opportunity to learn through unencumbered failures without dissipating the startup's endowments, thus enabling further iterations on different BMs.

For the Disciplined Entrepreneurship (Sull, 2004) method, entrepreneurs, instead of trying to ignore or avoid the uncertainty inherent in the business, must address it through a disciplined approach. This approach would be to formulate hypotheses regarding many aspects of the business and to conduct experiments aimed at testing these hypotheses, investing few resources and seeking to reduce uncertainty. The author positively contributes to the topics of how to properly formulate hypotheses about the business model dimensions and how to design and run experiments to test them.

Blank (2007) coined the term Customer Development to explain his method. It consists of a number of tools to increase the success of product development through better understanding about customers. One of the main concepts of this method is to balance and synchronize product improvement by developing the understanding of customer needs and demands ("search phase"), before scaling up the business model ("execution phase”). Customer Development largely contributed to the birth of the LS, as Ries (2011) himself admitted and Blank (2013) restated; more specifically, the Lean Startup largely overlaps with and resemble Customer Development's search phase, where the startup looks for business model validation from customers in order to achieve its longed-for objective of product-market fit.

Mullins and Komisar (2010), drawing from practical examples of organizations that have been successful after iterations and changes in their initial business model, show how 'Plan B' (or C, D, E, ...) can lead to a sustainable business model (in what they call a "Journey to Plan B"). The authors propose a framework and a monitoring panel to help entrepreneurs validate their hypotheses. This framework can be easily implemented along the LS methodology.

The review has also identified in the literature a number of tools or techniques that are used explicitly or implicitly by LS adepts. Such techniques, once internalized and adapted, can assist entrepreneurs in implementing the method and are summarized in Table 6.

\begin{tabular}{ccc}
\hline Reference & Tool or technique & Contribution to the Lean Startup \\
\hline Popper (1963) & Falsifiability & Formulation of hypotheses about business models \\
Takeuchi and Nonaka (1986) & Holistic Approach or Rugby & Ppproach \\
Deming (1986) & Lean and Agile & Product development iteratively \\
Ohno (1988) & Tools and techniques for product development and \\
continuous improvement
\end{tabular}


Making quick decisions for faster iterations

Selection and execution of hypotheses validation experiments based on estimations of associated risk

Balance between avoiding and taking risks

Table 6 - Tools or techniques to support the implementation of BMV steps

Among the various contributions by Popper (1963) to the philosophy of science is the idea of falsifiability. Popper explains that although a specific statement such as 'this swan is white' cannot be used to affirm a universal statement (such as 'all swans are white'), it can be used to show that another universal statement is false ('all the swans are black'). The idea of falsifiability is central to the scientific method and is indispensable for an entrepreneur formulating and testing hypotheses about business models.

Within software development research, the method described by Takeuchi and Nonaka (1986) is of critical importance. Through the Holistic Approach or Rugby Approach, they describe how multidisciplinary and self-organizing teams should adopt an iterative process to develop products faster and more flexibly. Such studies have been one of the cornerstones the Scrum, one of the leading methodologies of software development (Vlaanderen et al. 2011) and widely referenced in LS.

Deming (1986), Ohno (1988), Krafcik (1988) and Womack et al. (1990) described a series of tools and techniques that are key to the Lean philosophy and were widely cited and used by Ries (2011). These include the '5 Whys', just-in-time, kanban and Genba (also named as gemba). The same goes for another philosophy with a paramount importance in software - and by extension, product - development: Agile (Beck et al., 2001) and its methods or tools for fast iterations, incremental deliveries, interactions with different actors including customers and quick responses to change (e.g., see Rigby et al., 2016). As recognized in Ghezzi and Cavallo (2018), Lean and Agile two fundamentally intertwined philosophies backing the LS, and their related tools can support the entrepreneur in the implementation cycle of products and serve as a blueprint for constant improvement efforts.

Eisenhardt (1989) identified the criteria that lead an organization to make decisions more quickly, in what she called Fast Decision Making. Among other findings, the author noticed that the use of information in real time (as opposed to information aimed at planning for the future, such as 
estimates or forecasts), is critical to make faster decisions. The whole LS methodology is based on agile decision-making for rapid change and iteration, which is why the Eisenhardt's contributions are of great value.

LS as a whole has not delved deep in risk analysis (Frederiksen and Brem, 2017). Gilbert and Eyring (2010) explicitly focus on techniques for risk analysis, including a method of selection and execution of hypotheses validation experiments based on the estimation of associated risks. Such method can significantly contribute to the testing step of the LS, including a tool to identify which hypothesis to test first. Also in the area of risk analysis, Netessine (2011) proposes an appropriate balance between avoiding and taking risks as a powerful method of innovation.

Finally, if one considers the LS as a contemporary example of Incrementalism or Emerging Strategy approaches to strategy making, the methodology is also at the mercy of criticism, limitations and counterpoints previously raised by several authors in relation to such strategy approaches. In fact, the real value of a formal and structured planning for the success of an organization has been the subject of an intense and recent debate among scholars (Smith 1998; Brinckmann et al. 2010; Chwolka \& Raith 2012). Smith (1998) found evidence that small organizations using formal and traditional methods of strategic planning will perform better than those which opt for a dynamic and evolutionary process. Similarly, Brinckmann, Grinchnik and Kapsa (2010) found that a formal business plan can be of great value both for small businesses and for new companies, with greater advantage for the former. According to the authors, new companies should resort to formal but basic plans because of the inherent lack of information they possess. Finally, Chwolka and Raith (2012) claim that planning in advance can indeed be extremely relevant once some factors are favorable, such as good quality planning, favorable nature of the project and the entrepreneur's previous experience. To cope with such criticisms, recent studies (Ghezzi and Cavallo, 2018; Yang et al., 2018) point at the opportunity to integrate the LS with traditional business planning by: (i) running LS iterations and experiments to build metrics and figures coming from real customer feedbacks to validate a startup's business model; and (ii) feed the business plan with such metrics and figures, so as to make sure the business plan revolves around a validated business model.

\section{Conclusions}

Given the importance and popularity of the LS methodology, especially among practitioners, we identified and synthetized the scientific, academic, and professional foundations that precede, support and complement the main concepts, processes and methods advocated by the LS 
methodology. In addition, by contextualizing LS alongside other strategic and entrepreneurial tools explored in recent decades, we found a set of similar and precursory methods that can positively contribute to the implementation of the LS by providing new supporting processes and tools for the entrepreneur.

Our review suggests that the central principles of the LS are explicitly supported by the principles and techniques of the Lean philosophy that first emerged in the manufacturing context, and have high adherence with the principles and foundations of the Learning School of strategy and the Effectuation and Bricolage schools in Entrepreneurship.

Both the LS and the Learning School advocate that organizational learning is at the same time a critical objective and operational tool for strategy making. This conclusion is theoretically relevant, as it approaches the LS, a methodology with great repercussion and popularity in practitioner circles, to the ideas, concepts and tools developed in academic circles since 1958 by Lindblom. As such, the academic content about the subject - as well as criticism and limitations identified - can contribute to the improvement and further diffusion of the methodology.

Some recent studies we surveyed point at the implicit though significant nexus linking LS with Effectuation and Bricolage (e.g. Frederiksen and Brem, 2017; Yang et al., 2018), though such claims were still unsystematic and scattered in the LS-related literature, as they are not found in other works aiming to disclose the LS antecedent: for instance, Contigiani and Levinthal (2018) do not consider these entrepreneurship theories as a theoretical root for the LS. Through this review, we reinforce the claim that explicitly linking Effectuation and Entrepreneurial Bricolage with the LS will serve as a way to close the gap between theory and practice for business model experimenting and validation.

Previous authors that investigated LS antecedents argued that there seems to be enough evidence to support some of the claims made by Ries and the disciples of the movement regarding the efficacy of the methodology, but raise doubts about its widespread applicability (Frederiksen \& Brem, 2017). Our own research effort has identified a number of iterative methods and additional concepts that can be applied within the LS methodology, a finding that has significant practical implication in that they can help practitioners - both from startups and incumbent companies (Power, 2014) who implement the methodology. Thus, there is the possibility of improving the BMV process designed by Ries (2011) by adding, for example, milestone (Block and Macmillan, 1985) or checkpoint (McGrath and MacMillan, 1995) monitoring, or tools for designing immature 
products as defined by Lynn, Morone and Paulson (1996) evolved from the customer view (Blank, 2007).

Finally, both the validity and the innovativeness of the methodology proposed by Ries (2011) are highlighted. Even if situated into a constant evolution of concepts and tools dating back from the 1950s, the proposed methodology was able to bring together in an innovative and 'catchy' way disparate knowledge of different areas of expertise in an all-encompassing and coherent methodology with well-defined concepts, philosophies, techniques and tools. In addition, he had the clarity and originality to notice that the principles of the Learning School - which, at the time it was originally proposed applied only to very limited enterprise situations - would be perfectly applicable to a larger category nowadays: startups, inherently unstable and risky ventures, subject to constant change. At the same time, he more or less deliberately provided a pragmatic process to operationalize an effectual and bricolage approach to entrepreneurship.

The resulting LS process is significantly valuable to support BMV not only concerning a startup products, services and value proposition, but in all the constituting element of its business model, including marketing and sales - e.g. channels, customer relationship and pricing structure: such finding is evident in a recent study on digital entrepreneurship we reviewed (Ghezzi \& Cavallo, 2018).

Given the bibliographic nature of this research, the conclusions of this article have limitations in terms of research materials and practical implications. By defining a method for selecting specialized journals for analysis and research, the quality of information found is ensured, but full amplitude is not necessarily guaranteed. It is possible - even probable - that additional BMV methods and support tools, disclosed in untapped sources and references, can be used to support the implementation of LS. In addition, all links established between the LS and other theories, methods, tools or techniques were performed only at the theoretical level by subjectively analyzing the adherence, similarity and complementarity of ideas, but we did not perform any systematic empirical validation. Consequently, as possible venues for future studies and work, we suggest expanding the research with new and more diverse sources and carrying out practical and experimental validation of the LS deployment associated with one or more methods, tools and techniques identified in our research. A promising and relevant outcome of such sustained effort aimed at framing the LS theoretically will be a better connection between strategic and entrepreneurial theories and the startup actually practices.

\section{References}


Anthony, S. D. 2014. The First Mile: A Launch Manual for Getting Great Ideas into the Market. Boston, MA: Harvard Business Review Press.

Arteaga, R., \& Hyland, J. 2014. Pivot: How Top Entrepreneurs Adapt and Change Course to Find Ultimate Success. Chichester,UK: John Wiley \& Sons.

Baker, T., \& Nelson, R. E., 2005. Creating something from nothing: resource construction through entrepreneurial bricolage. Administrative Science Quarterly, 50(3), 329-366.

Beck, K., Beedle, M., Van Bennekum, A., Cockburn, A., Cunningham, W., Fowler, M., et al., 2001. Manifesto for agile software development.

Berglund, H., Dimov, D., Wennberg, K., 2018. Beyond bridging rigor and relevance: The three-body problem in entrepreneurship. Journal of Business Venturing Insights, 9, 87-91.

Blank, S. Startup Books. Available at: http://steveblank.com/books-for-startups/ [Accessed April 30 ${ }^{\text {th }}, 2018$ ].

Blank, S., 2007. The Four Steps to the Epiphany: Successful Strategies for Products that Win, USA: Cafepress.com.

Blank, S., 2013. Why the Lean Start-Up Changes Everything. Harvard Business Review, (May).

Blank, S. \& Dorf, B., 2012. Startup: Manual do Empreendedor, São Paulo: Alta Books.

Block, Z. \& MacMillan, I.C., 1985. Milestones for successful venture planning. Harvard Business Review, 63(5), 184 196.

Boyd, J., 1986. Patterns of Conflict. Available at: http://www.ausairpower.net/JRB/poc.pdf [Accessed April 30 ${ }^{\text {th }}, 2018$ ]

Brinckmann, J., Grichnik, D. \& Kapsa, D., 2010. Should entrepreneurs plan or just storm the castle? A meta-analysis on contextual factors impacting the business planning-performance relationship in small firms. Journal of Business Venturing, 25(1), 24-40.

Casadesus-Masanell, R. \& Ricart, J.E., 2010. From Strategy to Business Models and onto Tactics. Long Range Planning, 43(2-3), 195-215.

Chang, S.J., 2004. Venture capital financing, strategic alliances, and the initial public offerings of Internet startups. Journal of Business Venturing, 19(5), 721-741.

Chesbrough, H. \& Rosenbloom, R.S., 2002. The role of the business model in capturing value from innovation: evidence from Xerox Corporation's technology spin-off companies. Industrial and Corporate Change, 11(3), $529-555$.

Chrisman, J.J., McMullan, E. \& Hall, J., 2005. The influence of guided preparation on the long-term performance of new ventures. Journal of Business Venturing, 20(6), 769-791.

Chwolka, A. \& Raith, M.G., 2012. The value of business planning before start-up - A decision-theoretical perspective. Journal of Business Venturing, 27(3), 385-399.

Cortimiglia, M.N., Ghezzi, A. \& Frank, A.G., 2016. Business model innovation and strategy making nexus: evidence from a cross-industry mixed-methods study. $R \& D$ Management, 46(3), 414-432.

Cosenz, F., \& Noto, G. 2018. A dynamic business modelling approach to design and experiment new business venture strategies. Long Range Planning, 51(1), 127-140.

Deming, W.E., 1986. Out of the Crisis, Boston, Massachusetts, USA: MIT Press.

Drori, I., Honig, B. \& Sheaffer, Z., 2009. The life cycle of an internet firm: Scripts, legitimacy, and identity. Entrepreneurship: Theory and Practice, 33(3), 715-738.

Edison, H.,Smørsgård, N.M., Xiaofeng, W., Abrahamsson, P., 2018. Lean Internal Startups for Software Product Innovation in Large Companies: Enablers and Inhibitors. Journal of Systems and Software, 135, 69-87.

Eisenhardt, K.M., 1989. Making Fast Strategic Decisions in High-Velocity Environments. Academy of Management Journal, 32(3), 43-576.

Eisenmann, T., Ries, E. \& Dillard, S., 2011. Hypothesis-Driven Entrepreneurship : The Lean Startup. Harvard Business School Background Note 812-095, 1-23.

Fisher, G. 2012. Effectuation, causation, and bricolage: a behavioral comparison of emerging theories in entrepreneurship research. Entrepreneurship: Theory and Practice, 36(5), 1019-1051.

Frederiksen, D.L., \& Brem, A., 2017. How do entrepreneurs think they create value? A scientific reflection of Eric Ries' Lean Startup approach. International Entrepreneurship and Management Journal, 13(1), 169-189.

Furr, N., \& Ahlstrom, P. 2011. Nail it Then Scale it: The Entrepreneur's Guide to Creating and Managing Breaththrough Innovation. Lehi, UT: NISI Publishing. 
Furr, N., \& Dyer, P. 2014. The Innovator's Method: Bringing the Lean Start-Up Into Your Organization. Boston, MA: Harvard Business Review Press.

Ghezzi, A. \& Cavallo, A., 2018. Agile Business Model Innovation in Digital Entrepreneurship: the Lean Startup Approaches. Journal of Business Research, forthcoming.

Gilbert, C. \& Eyring, M., 2010. Beating the Odds When You Launch a New Venture. Harvard Business Review, (MAY).

Google Scholar, Top publications - Entrepreneurship \& Innovation. , p.1. Available at: https://scholar.google.com/citations?view_op=top_venues\&hl=en\&vq=bus_entrepreneurshipinnovation [Accessed April 30th, 2018].

Greenwald, T., 2012. Upstart Eric Ries Has the Stage and the Crowd Is Going Wild. WIRED. Available at: http://www.wired.com/2012/05/ff_gururies/all/1 [Accessed April 30th, 2018].

Gruber, M., 2007. Uncovering the value of planning in new venture creation: A process and contingency perspective. Journal of Business Venturing, 22(6), 782-807.

Haines, J.K., 2014. Iterating an Innovation Model : Challenges and Opportunities in Adapting Accelerator Practices in Evolving Ecosystems. In Ethnographic Praxis in Industry Conference Proceedings. 282-295.

Harms, R., 2015. Self-regulated learning, team learning and project performance in entrepreneurship education: Learning in a lean startup environment. Technological Forecasting \& Social Change, 100, 21-28.

Holweg, M., 2007. The genealogy of lean production. Journal of Operations Management, 25(2), $420-437$.

Kerr, W., Nanda, R., \& Rhodes-Kropf, M., 2014. Entrepreneurship as experimentation. Journal of Economic Perspectives, 28(3), 25-48.

Krafcik, J.F., 1988. Triumph of the Lean Production System. Sloan Management Review, 30(1), 41.

Landström, H., \& Harirchi, G., 2018. The social structure of entrepreneurship as a scientific field. Research Policy, 47(3), 650-662.

Levi-Strauss, C. 1966. The savage mind. University of Chicago Press.

Lindblom, C.E., 1959. The Science of “Muddling Through.” Public Administration Review, 19(2), 79-88.

Lynn, G.S., Morone, J.G. \& Paulson, A.S., 1996. Marketing and Discontinuous Innovation: The Probe And Learn Process. California Management Review, 38(3), 8-37.

Magretta, J., 2002. Why business models matter. Harvard Business Review Spotlight: Pratical Strategy.

Mansoori, Y., 2017. Enacting the lean startup methodology: The role of vicarious and experiential learning processes. International Journal of Entrepreneurial Behavior \& Research, 23(5), 812-838.

Martikainen, A., Niemi, P. \& Pekkanen, P., 2014. Developing a service offering for a logistical service provider-Case of local food supply chain. International Journal of Production Economics, 157, 318-326.

Massa, L., Tucci, C. L., \& Afuah, A., 2017. A critical assessment of business model research. Academy of Management Annals, 11(1), 73-104.

Maurya, A. 2012. Running Lean: Iterate from Plan A to a Plan That Works. Sebastopol, CA: O'Reilly Media.

McGrath, R.G., 2010. Business Models: A Discovery Driven Approach. Long Range Planning, 43(2-3), $247-261$.

Mcgrath, R.G. \& Macmillan, I.C., 1995. Discovery Driven Planning: Turning Conventional Planning on its Head. Harvard Business Review, 73(4), 44-54.

Miles, R. E., Snow, C. C., Meyer, A. D., \& Coleman Jr, H. J., 1978. Organizational strategy, structure, and process. Academy of management review, 3(3), 546-562.

Mintzberg, H., Ahlstrand, B. \& Lampel, J., 1998. Strategy Safari: A Guided Tour Through The Wilds of Strategic Managemen, New York, EUA: The Free Press.

Moogk, D., 2012. Minimum Viable Product and the Importance of Experimentation in Technology Startups. Technology Innovation Management Review, (March), 23-26.

Mueller, R.M. \& Thoring, K., 2012. Design Thinking Vs Lean Startup: A Comparison of Two Userdriven Innovation Strategies. In Proceedings of 2012 International Design Management Research Conference. Boston, USA, 151161.

Mullins, J. \& Komisar, R., 2010. A Business Plan? Or a Journey to Plan B? Sloan Management Review, (April 01, 2010), 1-5. 
Netessine, S., 2011. How to Build Risk into Your Business Model. Harvard Business Reiew, (May).

Ohno, T., 1988. Toyota Production System: Beyond Large-Scale Production, Portland, Oregon, EUA: Productivity Press.

Osterwalder, A. \& Pigneur, Y., 2010. Business Model Generation, Hoboken, New Jersey: John Wiley \& Sons, Inc.

Osterwalder, A., Pigneur, Y. \& Tucci, C., 2005. Clarifying business models: origins, present, and future of the concept. Communications of the Association for Information Systems, 15(May), 1-43.

Paternoster, N. et al., 2014. Software development in startup companies: A systematic mapping study. Information and Software Technology, 56(10), 1200-1218.

Picken, J.C., 2017. From startup to scalable enterprise: Laying the foundation. Business Horizons, 60(5), 587-595.

Popper, K., 1963. Science as Falsification. Available at: http://faculty.washington.edu/lynnhank/Popper-1.pdf [Accessed April 30 $\left.{ }^{\text {th }}, 2018\right]$.

Power, B., 2014. How GE Applies Lean Startup Practices. Harvard Business Review, Available at https:// hbr.org/2014/04/how-ge-applies-lean-startup-practices [Accessed April 30 ${ }^{\text {th }}, 2018$ ].

Quinn, J.B., 1978. Strategic change: "Logical Incrementalism.” Sloan Management Review, 20(1), 7-21.

Ratinho, T., Harms, R., Walsh, S., 2015. Structuring the Technology Entrepreneurship publication landscape: Making sense out of chaos. Technology Forecasting and Social Change, 100, 168-175.

Rigby, D. K., Sutherland, J., \& Takeuchi, H., 2016. Embracing agile. Harvard Business Review, 94(5), 40-50.

Ries, E., Startup Lessons Learned. Available at: www.startuplessonslearned.com [Accessed April 30 ${ }^{\text {th }}, 2018$ ].

Ries, E., 2011. The Lean Startup: How Today's Entrepreneurs Use Continuous Innovation to Create Radically Successful Business, New York: Crown Business.

Sarasvathy, S. D., 2001. Causation and effectuation: toward a theoretical shift from economic inevitability to entrepreneurial contingency. Academy of Management Review, 26(2), 243-263.

Smith, J. a., 1998. Strategies for start-ups. Long Range Planning, 31(6), 857-872.

Stinchcombe, A.L., 1965. Social structure and organizations, Chicago: Rand McNally.

Sull, D.N., 2004. Disciplined entrepreneurship. Mit Sloan Management Review, 46, p.71+.

Sykes, H.B. \& Dunham, D., 1995. Critical assumption planning: A practical tool for managing business development risk. Journal of Business Venturing, 10(6), 413-424.

Takeuchi, H. \& Nonaka, I., 1986. The new new product development game. Harvard Business Review, 64(1), 137-146.

Teece, D.J., 2010. Business Models, Business Strategy and Innovation. Long Range Planning, 43(2-3), 172-194.

Thelwall, M., 2008. Bibliometrics to Webometrics. Journal of Information Science, 34(4), 1-18.

Thongpapanl, N., 2012. The changing landscape of technology and innovation management: An updated ranking of journals in the field. Technovation, 32(5), 257-271.

Toyota Production Support Center, 2015. The Toyota Production System. Available at: http://www.tssc.com/tps.asp [Accessed April 30th, 2018].

Tranfield, D., Denyer, D., Smart, P., 2003. Towards a methodology for developing evidence-informed management knoweldge by means of systematic review. British Journal of Management, 14, 207-222.

Trimi, S. \& Berbegal-Mirabent, J., 2012. Business model innovation in entrepreneurship. International Entrepreneurship and Management Journal, 8(4), 449-465.

Vlaanderen, K. et al., 2011. The agile requirements refinery: Applying SCRUM principles to software product management. Information and Software Technology, 53(1), 58-70.

Vogel, R., Hattke, F., Petersen, J., 2017. Journal rankings in management and business studies: What rules do we play by? Research Policy, 46, 1707-1722.

Webster, J., \& Watson, R.T., 2002. Analyzing the past to prepare for the future: Writing a literature review. MIS Quarterly, 26(2), xiii-xxiii.

Wirtz, B.W., Schilke, O. \& Ullrich, S., 2010. Strategic development of business models: Implications of the web 2.0 for creating value on the internet. Long Range Planning, 43(2-3), 272-290.

Wohlin, C., 2014. Guidelines for snowballing in systematic literature studies and replication in software engineering. In: EASE'14. Proceedings of the $18^{\text {th }}$ International Conference on Evaluation and Assessment in Software 
Engineering.

Womack, J.P., Jones, D.T. \& Roos, D., 1990. The Machine That Changed The World, New York: Free Press.

Yang, X., Sun, S. L., \& Zhao, X., 2018. Search and execution: examining the entrepreneurial cognitions behind the lean startup model. Small Business Economics, 1-13.

Zhang, J., Wang, Y., Zhao, Y., 2017. Investigation on the statistical methods in research studies of library and information science. The Electronic Library, 35(6), 1070-1086.

Zott, C. \& Amit, R., 2013. The business model: A theoretically anchored robust construct for strategic analysis. Strategic Organization, 11, 403-411.

Zott, C., Amit, R. \& Massa, L., 2011. The Business Model: Recent Developments and Future Research. Journal of Management, 37(4), 1019-1042.

Zupic, I., Cater, T., 2015. Bibliometric methods in management and organization. Organizational Research Methods, $18(3), 429-472$. 